\title{
Global Mapping of Risks in Family Businesses
}

\author{
Ilyass Taki ${ }^{1}$ Badr Habba ${ }^{1,2}$ \& Taib Berrada El Azizi ${ }^{2}$ \\ ${ }^{1}$ LAREGO Laboratory, ENCG, Cadi-Ayyad University, Marrakesh, Morocco \\ ${ }^{2}$ Chair of Moroccan Family businesses, ESCA Ecole de Management, Casablanca, Morocco \\ Correspondence: Ilyass TAKI, Encg School, Cadi-Ayyad University, Boulevard Allal Al Fassi, Marrakech 40000, \\ Morocco. E-mail: Taki.ilyass@gmail.com
}

Received: April 21, 2021

doi:10.5539/ijbm.v16n8p122
Accepted: June 15, 2021

Online Published: July 20, 2021

URL: https://doi.org/10.5539/ijbm.v16n8p122

\begin{abstract}
This study aims to approach the potential risks of the family businesses, on the basis of extensive literature and theoretical researches. This paper first provides a global overview that summarize the key literature of the family business risks, categorized according to their specificities. Subsequently, the risk mapping framework proposed is inspired by the internal control objectives (Note 1) suggested by the COSO 1 and 2 standards. This helped draw a global mapping of risks that therefore constitutes a first global risk mapping in literature, which are likely specific to this type of business. The result of our paper aims to enrich the theory and help managers to anticipate and manage family business risks.
\end{abstract}

Keywords: risks, categorization, mapping, risk areas, family business

\section{Introduction}

Research on the family business continues to expand and consolidate its relevance and legitimacy. This type of business, long marginalized by researchers, turns out to be, during the last decades, not only a dominant form in many economic sectors, C. Bernard (2015); but also, one that needs the most attention. These companies prioritize their sustainability over the search for short-term profits. They are known for their "Patient Capital" (Beldenhill, 2018). This strategic choice influence their risk management practices. In this regard, family-owners are constantly seeking a balance between (i) the pursuit of growth through long term investments, necessary to ensure the sustainability of the business and (ii) risk aversion needed to protect the family heritage (Basly, 2020). Agency theory has often been used to describe and analyze the agency relationship in family businesses, most often in comparison to non-family businesses. Recently, theories have been established to analyze in depth the likelihood dysfunctions of the family business, including the main theories of behavioral governance (G. Hirygoyen 2008, 2009), social networks (Gulati \& Gargiulo, 1999) and stakeholders (Charreaux \& Desbrières 1998). But in many cases, the categorization of the family business risks ultimately seems to be overlooked. Several studies on such as: Visser and Scheers, (2018), typology of risks in four categories, Gómez-Mejía et al. (2007); Daniell and Mc Cullough, (2013); categorization of risks by areas, are the most apparent on this subject. Other investigations appear to restrictively analyze risks in a family company, meanwhile recent works have included the quality of family ties as important criterion in their analytical approach (Schulze, Lubatkin, \& Dino 2003; Labaki 2007), succession (Sharma et al. 2001), nepotism (Faccio and Lang (2002), principal / agent relationships (Eisenhardt, 1989), and majority shareholders / minority shareholders (Fan and Wong, 2002). However, much remains to be done to better assess the risks of family businesses in a larger global approach context. This concerns the roles of family, management, owners and other stakeholders, in the family business sustainability as an organization with its own codes, rules and special governance mechanisms. The challenge is to determine the extent of which the presence of risks from multiple sources influences and determines the fate of the company. This work is part of a preliminary process. We believe that developing a kind of mapping for risks of the family business would undoubtedly be an important step to have a global vision of the potential risks of this business. This ultimately will identify, assess and subsequently, manage them in a rational manner.

A risk classification strategy is a key starting point for risks identification that the family business faces. A risk can therefore be cataloged in a class according to the hypothesis-driven risks. Thus, taking into account the risk typologies mentioned in most academic backgrounds (Thea Visser \& Louise van Scheers, 2018, risk typology in four categories), (Gómez- Mejía et al., 2007; Daniell \& Mc Cullough, 2013; categorization of risks by domain) 
and the results of studies carried out on risks in the context of behavioral governance (G Hirygoyen, 2008, 2009) we agreed to catalog the risks in three categories that would allow to analyze clearly the main risks of the family business at Strategic, Operational, Reporting, and Compliance levels and their challenges:

- Risks related to the application of instructions and guidelines relating to the company's strategic decisions and projects

- Risks related to the functioning of internal processes and the safeguarding of assets

- Risks related to the reliability of financial and non-financial information and compliance with laws and regulations

this paper contains 3 paragraphs, each of these levels constitutes a paragraph, including specific risks at each level and the global mapping of risks will be listed in a table at the end of our paper.

But it is first important to note the meaning given to 'risk'.

$\checkmark$ According to the AMF (Note 2): the risk represents the possibility of an event occurring and the consequences of which could affect people, assets, the environment, the company's objectives or its reputation. A risk can represent a threat or a missed opportunity. It is characterized by an event, one or more sources and one or more consequences.

$\checkmark$ In a universal approach, the risk (Note 3) according to COSO 2 is the "Possibility of an event occurring and having an adverse impact on the achievement of objectives". Let us now analyze these three categories of risks.

\section{Risks Linked to the Application of Instructions and Guidelines, Relating to the Company's Strategic Decisions}

At the level of strategic decisions, the concept of strategy covers a complex reality (Desreumaux, 1993; Mintzberg et al., 1998). In this paper, company's strategy is considered as the set of actions that determine the lasting success of an organization that covers actions, decisions and "decision makers ". this paper answers the following question: What are the implications of family member's position about risk and investment horizons, on the behavior of the family business in terms of strategy?

\subsection{The Ownership Structure and the Strategic Orientations Risks (Note 4)}

The ownership structure contributes obviously in the family business's life. In general, it influences significantly the strategic decision-making process, on top of that, it affects also the strategic choices and behaviors (Zahra, 1996). According to the agency theory, when leaders are owners, they pursue risky activities and align managerial decision-making with the owner's interests (Katz \& Niehoff, 1989). In this context, Katz and Niehoff (1999). Xiao et al. (2001) showed that family business owners are more risk tolerant than non-owners. In some cases, the rivalry may emerge in strategic issues. For example, in a family business where cousin consortiums do not agree on the vision of the company, the risk tolerance, and responsibilities to bear, the rotation of managers is low, because their future strongly relies on the company. Which means that long-term investment should be sought while favoring the rooting of the manager. In this context, Mignon (2000) pointed out the sustainability of control and management necessarily secure a very long-term horizon to the company's strategic decisions. However, controversial situations may occur giving that the involvement of the family can lead to a paradoxical situation. Specifically, family members that share values and norms can shape their personalities and behaviors and so more on, their visions and goals. The influence they exert on strategy can only be multilateral. According to Gersick et al. (1997), as the family grows and expands, the correspondence between family values and the company values becomes increasingly difficult to ensure. In addition to family influence, the organizational complexity of family businesses contributes to the global influence on executive managers, and on the work of both the external partners and the external members that are on the administration board. Moreover, Mustakallio and Autio (2001) found that the quality of the decision-making process in family companies strongly attributable to many formal and informal governance mechanisms. Specifically, the use of structural elements of governance (Board administration) for the strategic decision-making of the family business, remains rare. As opposed to the strategic vision and the exercise of the power by the owner that take place most often in an informal manner (Melin \& Nordqvist, 2000). Thus, even if they offer the opportunity to discuss important strategic questions, the meetings of the board of directors are nonetheless focused on questions of formalities (Melin \& Nordqvist, 2000). Also, other real decisions are made elsewhere either at random meetings or private interactions between influential family actors. If the strategic process is implicit and not formalized, family businesses will undergo a multilateral influence as exemplified below; in the next paragraph, we expose the influence of family control on specific cases of diversification strategies. 


\subsection{Ownership Structure and Risks Linked to Diversification Strategies (Note 5)}

Following the assumptions of Shleifer and Vishny (1986), Anderson and Reeb (2003b), the desire to reduce risks in the context of family businesses would lead them to be more diversified than non-family businesses. But their results have shown the opposite. The manager's prudence discourages costly investments with uncertain profitability. According to the study done by Azoury and Salloum (2011) the strategic behavior of these companies is rather conservative (Note 6). Gomez- Mejia et al. (2010) reported that businesses under family control tend to diversify less, even if this implies greater commercial risk. They explain this essentially by the existence of conservatism in the strategic behavior of family businesses, by rejection of the use of debt. Also, the fact that the managers of family businesses fear that diversification will contribute to reducing their control over the business by causing the need to integrate new managers presenting new expertise. On the other hand, Amihud and Lev, (1999) have given an explanation of the link between ownership structure and level of diversification through agency theory (Eisenhardt, 1989). They concluded that the problem is one of risk sharing when the principal and the agent do not have the same concept of risk. Thus arise conflicts of interest at the organizational level between the principal and the agent. The centralized and poorly formalized decision-making processes in the company give way to the intuition of the manager ultimately making the investment or non-investment decision. Establishing new relationships may appear necessary, but it may increase the risk and further reduce the chances to survive (Zahra, 2010). Empirical studies show how socio-emotional wealth (Note 7) is a potential dominant paradigm in the family business field and influences strategic choices. Diversification reduces the socio-emotional wealth of the family. The results of the study done by Denis et al. (1997) also show that there is a negative relationship between the existence of a group of majority shareholders and the level of diversification.

Let us now analyze the influence of the family ownership structure on investment opportunities.

\subsection{Ownership Structure and Risks Linked to Investment Projects (Note 8)}

The success of an investment in family businesses depends on certain criteria, mainly related to managers: the degree of their vigilance in the selection of projects, the clarification of their financial decisions, the planning in advance of the continuity of their businesses, and the intention of carrying out a given level of investment. This last criterion, considered by (El mabrouki \& al, 2012) (Note 9), as the most important arises from the conjunction of various elements including specifically the family decision structures and the financial constraints felt or foreseeable by the leaders. The family business differs by percentage of Control exercised by the family. The outside owners (usually minority), would support the same investment project risks as in non- family businesses because they benefit only from the appreciation of shareholder value (Schulze, Lubatkin and Dino, 2003). They would be indifferent to the level of risk inherent in any particular investment undertaken by the company because they can reduce it by dividing their portfolios. In contrast, the owners controlling the company think in terms of utility, and not be so willing to bear the risks in line with their preferences for certain objectives (Shulze and al. 2001). These objectives include not only the financial and non-financial benefits, but also the usefulness of the ability to exercise authority and the choice of investments. Fama and Jensen (1983) add that due to the lack of diversification of his risk, due to an investment both human and financial in the same organization, the manager-owner will favor the least risky investments and financing. He fears, at the same time, of losing his job and his financial investment within the company that he leads.

\section{Risks Related to the Functioning of Internal Processes and the Safeguarding of Assets}

Susanne Beck and Reinhard Prügl (2018) note that this risk is present in family businesses, which has its origins in the triplet present in the head of companies: Family, management and ownership. In the literature, the two following dilemmas: Family, Business and Actor - Family Community, are the source of what we call "the behavioral biases". Thus, G. Hirigoyen has developed an approach relevant to the governance of the family business; "behavioral governance", which would allow us to clear the behavior of different actors in the operation of the family business and risks through these behaviors.

\subsection{Risks Related to Family Dynamics}

If several theoretical and empirical studies consider the family as a homogeneous or monolithic group with converging interests Gersick et al. (1997), other studies underlined that differences that may arise within the family and role conflict can lead to behaviors that do not go in the direction of the best interests of the company (Mk Conaughy et al., 2001). If we assume that the interests of the first generation are convergent, divergences are notable for the following generations, as indicated Astrachan et al. (2003).

In addition, due to lack of preparation or even, absence of succession planning, the periods of succession are 
often the occasion when family ties weakens and the degree of mutual trust decreases (Steier, 2001, Cabrera-Suarez et al., 2001, Hirigoyen, 2007, Labaki, 2007). In this sense (Drozdow \& Carroll, 1997) note that it is difficult for members of future generations to trust other family members in the same way as they trusted their own parents.

\subsection{Risks Related to the Presence or Failure of the Family Unit}

The family unit is Considered as collective capital (Note 10), an aggregation of financial wealth, strategic wealth and shared values to which each member adheres. The family is also characterized by the possession of a collective legal personality exercised by the head of the family . Many researchers, such as Martine Segale and Claudine Attias- Donfut (2007), studied the role of grandparents who must be the pivot that assures solidarity between generations and within the family ; between parents, the sister's children and their grandchildren. When family unity is reached it can lead to strong family control over the business. The literature puts forward ideas on this subject as to the consequences of this strong family control. Analysis is based on corporate governance. In other words, it is necessary to refer to the regulations which govern the company, to understand the legitimacy given to the actors of the company to act. This consideration of the quality and nature of family ties and their impact on the dynamics and performance of the family business has been the subject of recent work (Schulze et al. 2001, Olson et al. 2003, Miller and Le Breton-Miller 2006, Labaki 2007) (Note 11). For Astrachan and McMillan (2003), one of the reasons the family unit is the desire to enjoy family fruits of this project, this feeling is particularly strong for the two first generation when the values held by the family business are close to those worn by the family. But as the family grows and disperses, the correspondence between family values and corporate values becomes more and more difficult to ensure. Recognition of a risk of rupture of this unit and its management by the family are major concerns that the company should face in the context of family complexity (Bauweraerts et al. 2013). Among the negative aspects of the abuse of family control, the concentration of family ownership would limit the exercise of market discipline (Shleifer \& Vishny, 1989) and have a negative impact on financial value. It would also cause a diversion of wealth by family controllers which would be to the detriment of the minority, a diversion of investments for personal purposes (Mork et al., 1988) and would lead to a rejection of investments not in accordance with the family interest penalizing by that the strategic and financial values.

\subsection{The Risks of Conflicts}

Certain types of conflicts can be beneficial when they lead to compromises and agreements, but others can have a negative impact on business performance (Kellermanns \& Eddleston, 2004). Among the differences that have weight on the company's management, the risks linked in particular to interactions between control and ownership of the family business.

\subsubsection{Conflicts Related to Family Control}

When we talk about family businesses, the concept of conflicts within family members comes to the fore. Understanding the sources of conflict is important for the management of family business . These conflicts can arise especially when the rules are not well established or generally followed, and family ties often cause the problem to worsen. Hirigoyen (1985) confirms that family businesses are not exempt from conflicts stemming from family problems. It is very common that intense conflicts take place within the family controlling the company. They involve either family members of the same generation, or of different generations, or oppose family members to outside employees (Gersick et al., 1997). The dispersal of ownership within family businesses leads to a divergence of interests between the family members who run the business, often with a majority stake and the other owner members (Schulze et al., 2003).

\subsubsection{Conflicts Agency}

The separation between ownership and management is a source of conflict which causes agency problems. Depending on the degree of divergence between the objectives and interests of managers and shareholders. Information asymmetry has a role in this area. The leader is in daily touch with the business environment, unlike the family owners, he can be able to manage his behavior to root and benefit himself (Charlier \& Lambert, 2013). In this context the first Type of conflict may be apparent, especially in the absence of alignment of interest, and rigorous family control. The second type of agency conflict, is apparent in the case of convergence of interests between management and the family shareholders, the owners try to expropriate the minority shareholders. As a result, the wealth of majority family shareholders grows to the detriment of non-family minority shareholders.

\subsubsection{Risks of Conflicts Related to Shareholder Governance}

The "shareholding" mode of governance has its roots in agency theory. The company is considered as a knot of 
contracts at the center of which is the shareholder / manager relationship. The shareholder is seen as the sole legitimate owner of the business. In this context, the main issue of governance is to encourage the manager to maximize the wealth of the shareholders. As soon as the capital is dispersed among several members, the shareholder / manager relationship becomes a source of agency conflicts, leaving more latitude to the manager.

\subsubsection{Risks of Conflicts Related to Partnership Governance (Stakeholder)}

According to the Stakeholder Theory (TPP) (Note 12), the company should not be attentive only to its (family) shareholders but to all the actors with whom it is in contact. The valuation of their interests conditions their attitudes towards the management of the company:

- For the family, the managing shareholder is considered as representing the interests of the whole family. In this sense, trust is the substitute for explicit contracts.

- For employees and non-family managers, taking their expectations (rights and wishes) into account is of great importance. Thanks to his discretionary power, the manager can establish contracts with the various stakeholders, in particular the employees, which will allow him to increase his roots and maintain the dependence of the employees on their managers (Salloum \& Azoury, 2009). These implicit contracts are difficult to control by the owners and even by the board of directors.

\subsection{Risks Linked to Behavioral Biases}

The term bias refers to a systematic deviation of logical thinking and rational relation to reality. Thus cognitive bias is considered as a distortion in the cognitive processing of information. By mobilizing work on emotional and cognitive biases in a context of behavioral governance G. Hirigoyen (2008), we strive to understand its strategic role in the family business. Both cognitive and emotional biases; individual and collective (Greenfich, 2005) generate additional agency costs and increase the risk inherent in the family business, which can lead to its disappearance. We analyze the main bias related to nepotism, to altruism and the management of the company

\subsubsection{The Bias of Nepotism}

Family patronage is recognized as a tendency to hire or favor friends or family members in the business, only because of blood ties or established relations with these people. In fact, hiring family members has a negative effect on the business unless they are recruited on the basis of their skills and are well suited to the project. Among its implications, nepotism lowers employee morale and hinders activities, especially if those hired seek to fill a job without fulfilling their responsibilities. This act, justified or not, can cause employees to work less. In addition, these people, abusing family ties, will always feel as if they have a right or a privilege over the others. A study by Faccio and Lang (2002) estimates that human resources management is not effective in family businesses due to a lack of objectivity by managers, a certain managerial inflexibility, nepotism and the various pressures of the family (Note 13).

\subsubsection{The Biases of Altruism and Philanthropic Donations (Note 14)}

If for Schulze et al. (2003), altruism is a recognized as a practice between parents and their children, other authors such as Bergstrom and Stark (1993) and Dyer (2003) show that altruism also emerges in other types of family relationships such as fraternal ties. This altruism when it exists, it is by necessity or by personal interest. And the individual selfless always expects something in return for what he gives. Hirigoyen $(2008,2009)$, believes that altruism as a behavioral biases may affect the performance and constitutes a form of governance depending on the degree of symmetry between the family involved in the business. The absence of this symmetry is the source of several dysfunctions (Hirigoyen, 2009). Altruism (Note 15) of the family leader has other disadvantages. It can encourage the family members to conceal information and create agency problems. As altruism can compel the family leader to take reckless measures that could potentially have harmful consequences for all stakeholders (Jensen, 1998; Schulze et al. 2001). According to (Hirigoyen, 2008), it can lead to a devaluation of the performance. Wu (2002) for his part, shows that (parental) altruism can lead the family business to deviate from the objective of maximizing value.

Schulze et al. (2001) add that when the value of altruism is "cracked" in families, feelings of rivalry can replace the feelings of love and affection that characterize altruism (Lundberg, 1994). In addition, since family ties tend to be unbalanced according to stages and family size, they can lead to asymmetric altruism. The source of inefficiency is the recipient's tendency to waste the donation quickly in order to receive more resources from another agent and to behave like a "whiner".

\subsubsection{Risks Imputed to the Selection of Directors}

The family business, constrained by its development, should seek talent capable of taking responsibility for its 
management. Thus the family business is faced with various challenges in the selection and management of the talents of its managers. While in some cases the name of the successor is obvious if he agrees to the terms adjudicated by the company, in other cases several family members are all predisposed to succeed. Therein lies the problem of selection. In contrast, according to the results of a study done on the succession of family mangers (Note 15), we find that the motivation of the next generation to take over the family business has fallen to a record low. Thus, only $20 \%$ of all students from entrepreneurial families are in principle ready to ensure succession in the company. Consequently, the needs of managers external to the family take on enormous importance, especially when no family member is suitable for these missions and special expertise is required.

\subsubsection{Succession / Transmission Risks}

-The managing shareholder in the family business between personal sustainability and organizational sustainability

The desire to perpetuate both the business and the family unit, brings to light a major objective that is absent in other forms of business: succession-transmission. The managing shareholder of the family business finds himself in dialogical tension between two poles that are often difficult to reconcile: personal sustainability and organizational sustainability. The question of the rooting of the leader is a question that has been fairly and widely addressed in the literature for a few years. Developed by Shleifer and Vishny in 1989, the theory of rooting (Note 16) consists of an opportunistic vision of the leader. Agency conflicts in these companies are associated with entrenchment (Morck et al., 2005). Rooting is a way for managers to increase their discretion. Through this process, he increases his bargaining power.

-Succession problems

The main risks for the succession of the family business come from the lack of communications mainly from the head of the household, the lack of planning, unclear roles of family members in the business (Lipitz and Hauser, 2016). While in some cases the name of the successor is obvious, in other cases several members of the family are all predisposed to succeed. It follows that only a few of these companies manage to pass the milestone of several generations. Hirigoyen (1987); Astrachan and Kolenko (1994); Allouche and Amann (2000). In addition, the wishes of the heir and the predecessor are preponderant in the construction of a context conducive to a successful succession.

\section{Risks Related to the Reliability of Financial and Non-Financial Information and to Compliance with Laws and Regulations}

We take up the agency relationship, as Jensen and Meckling (1976) defined it, "a contract by which a (principal) engages an (agent) in order to take decisions on his behalf and act for his account". The agency theory attempts to offer explanations for the problems of transparency of financial information as soon as there is an agency relationship. Altman et al. (2010) point out that the risks of the family business (Note 17) are classified according to financial and non-financial information. Financial information refers to the accounts of family business, information concerning the assets, the measures retained earnings, the working capital ... Non-financial information is related to the size, age and ownership of the company. The risks due to financial information will be analyzed through the Reporting financial and sharing of information within the company and with stakeholders. The relationship between the family business and results management will be studied through two distinct effects from the agency theory: the alignment effect and the effect of rooting. (Note 18) Potential risks can also affect legal and tax watch (Mark Little, 2018). We integrate into this axis the company's responses to variations in the external environment. Non-financial information is taken into account as a complement to purely financial information and as a vital aid for a good understanding and appreciation of the company (Pigé, 2013).

\subsection{Financial Information Transparency Issues (Note 19)}

We focus on the financial information published by the company because it is reflecting the image of the company and it is on its basis that we can make a judgment on its governance and its profitability. Financial reporting can be defined "as any deliberate communication of financial, quantitative or qualitative, mandatory or voluntary information conveyed by formal or informal media" (Gibbin et al., 1990). Several studies have privileged to measure the quality of financial publication through the annual report following the results of Lang and Lundholm (1993) which show that the overall level of financial publication of firms is positively linked to the level of information contained in their annual reports. According to Sacristan -Navarro and Gomez- Anson (2007), family businesses experience information asymmetry. We focus on this risk of expropriation of minority shareholders because it is due to the non-transparency of information and this, by examining the following 
determinants: the concentration of ownership (Chau \& Gray, 2002; Fan \& Wong, 2002), and family control (Chen \& Jaggi, 2000; Chau \& Gray, 2002; Ali et al., 2007).

\subsubsection{The Concentration of Ownership and the Risk of Expropriation of Minority Shareholders}

When the business family is managed by family members, they tend to have outstanding concerns about the sustainability of the company and a strong incentive for the supervising (Andres, 2008). Fama and Jensen, (1983), Schulze et al. (2001) emphasize that a majority participation of family members can create a conflict of interest between family shareholders and minority shareholders. This conflict of interest manifests itself in various forms: family shareholders can, for example, engage in selling the assets and products of the business at abnormally low prices, providing well-paying jobs to less qualified relatives (Ward, 2011) or pay unreasonably high wages for family managers. The concentration of ownership increases this risk by offering blockholders (Note 20) the possibility of reducing the level of public information (Laidroo, 2009) while avoiding disputes (Chau and Gray, 2002). Hope and Thomas (2008) show that the opportunism of managers increases the risk of altering financial reporting. They show a positive relationship between the dispersion of capital and the quality of the publication. For their part, Fan and Wong (2002) find in their study of seven Asian countries a negative relationship between the concentration of capital and the quality of accounting information. The authors point out that the type II agency conflict leads controlling shareholders to behave opportunistically and publish information for the sole purpose of serving their own interests, which affects the quality of the publication (Fan and Wong, 2002).

\subsubsection{The Control Family and Risk of Impaired Financial Information}

According to Ratten (2015), family businesses are prepared to take risks. On the one hand, family control over the board of directors reduces the effectiveness of independent directors in controlling the quality of financial information (Chen and Jaggi, 2000). Moreover, the advice dominated by family members, instead of monitoring the action of managers and guarantee the interests of minority shareholders, sit on the board for the sole purpose of maximizing the interests of the family (Ho \& Wong, 2001). Thus, family control increases the risk of expropriation of minority shareholders (Ali et al. 2007). The study of Yoshikawa and Rasheed (2010) shows that family members who are actively involved in the business of managing and / or sit on boards, have a low demand for public information that they in feature already.

Many are the studies which emphasize that the fact of ensuring the functions of CEO and Chairman of the Board by the same person, threatening managerial control as long as this person, in his capacity as Chairman of the Board, would be more aligned with management than with shareholders (Hope and Thomas, 2008). The study of Forking (1992) conducted in Great Britain shows that the person occupying the chair of the Board and General Manager also presents a threat to the quality of the information published. Ho and Wong (2001) conclude that the leadership unit structure plays to the detriment of the quality of information.

\subsection{Regularity of Financial Information (Note 21)}

Information given to the public must meet a number of characteristics required by law. It must be exact, complete and precise, sincere, relevant and equally accessible to all investors at the same time, in order to avoid creating an asymmetry of information which would advantage certain investors to the detriment of others.

\subsubsection{Risks Linked to the Organization and Accounting and Financial Information (Note 22)}

Since family businesses can be deeply rooted in communities, reputational damage can be serious (Arregle et al., 2007). As a result, family businesses may be more likely to avoid often seeking legal redress and to face various regulatory compliance issues relating to the qualification of the auditor, change of auditor and filing accounts late because they are often indicators of financial difficulties (Altman et al. 2010). Thus, the very first quality criterion for financial statements is their compliance with the standards in effect.

The quality of the accounting and financial information published largely depends on the reliability and regularity of the transmission and the exhaustiveness of the information prepared in the "upstream processes", of accounting production and closing of accounts and therefore the control of risks that may affect these processes. The quality of accounting and financial information depends in particular on criteria (Note 23) the respect of which should be sought, so that the information contained in the financial statements is regular and fair. The existence of risk management and accounting and financial internal control systems is of great importance. The board of directors must make sure that significant or major weaknesses internal control risks reported by the auditors are taken into account in the corrective actions implemented by the company.

\subsubsection{The Risks in Results Management}


"Family businesses cannot survive without financial success. And at the same time, financial success is not the only goal that most family businesses pursue" (Yu et al., 2012). Thus, the financial strategy pursued will generally be more cautious than in non-family businesses (Hirigoyen, 1984; Gallo \& Villaseca, 1996). Self-financing is the preferred financial resource (Harvey, 1999). Our analysis will be based on the effects of alignment of interests and entrenchment.

The power in the family members is likely to discipline leaders (Shleifer \& Vishny, 1986). This convergence of interests has an alignment effect and allows, on the one hand, better support for agents (Charlier \& Lambert, 2013 ) and, on the other, an alignment of the interests of controlling family shareholders and those of managers. Which is synonymous with less management of results. This leads to transparency and quality of financial and accounting information, (Mard \& Marsat, 2012) and guarantee the quality of financial statements. On the other hand, the rooting effect makes it possible to maximize the wealth of controlling shareholders to the detriment of minority shareholders (Shleifer \& Vishny, 1997). (Caby \& Hirigoyen, 2002) observe that the combination of control and management generates a type II agency conflict; the practice of results management is adopted with the aim of safeguarding the family patrimony in order to ensure an intergenerational transmission (Pichard-Stamford, 2002). That which has a negative impact on the quality of financial reporting.

When the manager is external, he adopts a behavior of non-alignment with the controlling shareholders since he can take decisions going against the interests of the shareholders. Non-alignment gives the manager the opportunity to maximize his private benefits at the expense of shareholders or creditors (Christie \& Zem, 1994). This divergence leads to a lower quality of financial information.

\subsection{Non-Financial Information}

In recent years, non- financial information has gradually appeared in various corporate publications. Indeed, organizations are providing more and more information that does not directly deal with financial data. The information not financial is intended to complete purely financial information; it is today presented as a vital aid for a good understanding and appreciation of companies (Pige, 2013).

Non- financial information is presented today as a major aid for a good understanding and appreciation of companies (Pigé, 2013). However, there is no synthetic definition and the various authors very often perceive it as the opposite of financial information (Poincelot \& Wegmann, 2005; Protin et al., 2014). Investors and creditors of companies then feel the need to have as much information as possible about the economic and organizational potential of a company in order to allow them to allocate their resources in an optimal way (Zogning, 2014). The government and institutional bodies (Note 24) encourage companies to disclose to the public the maximum amount of information to stakeholders that may affect the results. The same applies to shareholders or partners who must be informed of the internal control and risk management policy.

\subsection{Questions of Ethics and Social Responsibility (CSR)}

The concepts of ethics and social responsibility were first defined in terms of individual virtues such as integrity, fairness, trust, respect and empathy (Murphy, 1999). The question was to measure whether the company as an organization was virtuous, whether by applying to the company the virtues attributed to the individual and / or by linking the virtue of the company to the satisfaction of the party's stakeholders (Cameron, Bright \& Caza, 2004; Chun, 2005). More recent developments have rather defined CSR as the capacity of the company to have satisfactory relationships with all of its stakeholders (Freeman, 1984; Clarkson, 1995). Other work on the strong point that the link between family business employees and managers can turn into blind obedience, and lead to the excesses (Kets de Vries, 1994) and where the emotional ties can promote harmony, but also destructive hatred (Tagiuri \& Davies, 1996).

Each of the actors of the family business can indeed adopt opportunistic behaviors, whether they are the shareholders-members of the family (Bertrand and Schoar, 2006; Claessens, Djankov, Fan, \& Lang, 2002), managers who are members of the family. (Chrisman, Chua, Kellermanns, \& Chang, 2006), children in their relationships with their shareholder parents due to the moral hazard induced by parental altruism. Employees who are not family members may also come into conflict with the parent shareholders because of the favoritism enjoyed by children (Lubatkin, Schulze, Ling, \& Dino, 2005). Minority shareholders can also be harmed by the shareholder-managers of the family business (La Porta, Lopez-de-Silanes, Shleifer, \& Vishny, 2000). In addition, there are multiple possibilities of tensions in the event of succession (Lansberg, 1988; Kets de Vries, 1994, Cadieux and Lorrain, 2002. The family business as seen by agency theory is therefore far from being a place of social cohesion, the informal common values put forward in a company may not respect the laws in effect (Warren, 2003). 


\section{A Overall Risk Cartography Kinds of Family Business}

The risk mapping can be defined (Note 25) as "the process of identifying, assessing, prioritizing and managing the risks inherent in the activities of an organization. It is an essential lever for risk management and forms the basis of the risk management strategy". This investigation leads to identifying the roles and responsibilities of each actor and at each stage of the processes. Knowing that All the activities presenting a risk for the company should be integrated into the cartography, it seems that a good number of risks are not taken into account. In addition, the granularity of the risks is limited to the actors who are sources of the risk. The mapping is therefore global and is limited to the allocation of each risk category to the actor causing the risk (family, owners, management, other stakeholders).

Table 1. The global mapping of the typical risks in the family business

\begin{tabular}{|c|c|c|c|}
\hline \multirow{2}{*}{$\begin{array}{l}\text { Categories } \\
\text { of risks }\end{array}$} & \multicolumn{3}{|l|}{ Risk factors } \\
\hline & Risk areas & Types of risks & $\begin{array}{l}\text { Risk } \\
\text { domains } \\
\text { actors }\end{array}$ \\
\hline \multirow{7}{*}{$\begin{array}{l}\text { Typical risks } \\
\text { linked to the } \\
\text { application of } \\
\text { instructions } \\
\text { and guidelines } \\
\text { relating to the } \\
\text { company's } \\
\text { strategic } \\
\text { decisions }\end{array}$} & $\begin{array}{l}\text { Ownership structure } \\
\text { and risks linked to } \\
\text { strategic directions }\end{array}$ & $\begin{array}{l}\text { Strategic orientation is done informally. The long term perspective implies } \\
\text { sustainability of management. Leaders are reluctant to develop written strategic } \\
\text { plans. Implicit and non-formalized nature of the strategies. meetings of the } \\
\text { board of directors are nonetheless focused on formalities } \\
\text { The owners are predisposed to make risky decisions provided, they take } \\
\text { advantage of them alone. They are risk tolerant but there is some rivalries over } \\
\text { the global vision. } \\
\text { Multilateral influence of the family at all stages of the strategic process. Family } \\
\text { values are integrated into the business even if they are contradictory to it. } \\
\text { Decisions must first adapt to the demands of the family. }\end{array}$ & Management \\
\hline & The ownership & $\begin{array}{l}\text { The manager's prudence discourages costly investments with uncertain } \\
\text { profitability. Intuition guides the manager in investment or non-investment } \\
\text { decisions. Managers fear that diversification will help to reduce their control } \\
\text { over the business. Organizational conflicts of interest between the principal and } \\
\text { the agent }\end{array}$ & Management \\
\hline & $\begin{array}{l}\text { associated with } \\
\text { diversification }\end{array}$ & $\begin{array}{l}\text { Conservatism. Lack of risk diversification. Refusal to use debt. Conflicts of } \\
\text { interest between the principal and the agent at the organizational level. The } \\
\text { majority shareholders, in opposite of the minority shareholders, are in favour of } \\
\text { reducing the level of diversification }\end{array}$ & The owners \\
\hline & & $\begin{array}{l}\text { Family culture can have a negative impact on far-reaching decisions. Family } \\
\text { control prohibits diversification even if this implies greater commercial risk. } \\
\text { The diversification reduces socio-emotional wealth family }\end{array}$ & Family \\
\hline & $\begin{array}{lr}\text { Ownership } & \text { structure } \\
\text { and risks } & \text { associated } \\
\text { with } & \text { investment } \\
\text { projects } & \end{array}$ & $\begin{array}{l}\text { When the manager is the owner there is a conflict relating to the objectives of } \\
\text { the parties sharing ownership. The external owners, (generally minority), would } \\
\text { be favourable to the investment projects even risky. The owner-manager, } \\
\text { favours low-risk investments and financing, for fear of losing his job and his } \\
\text { financial investment within the company he manages } \\
\text { The owners controlling the business reason in terms of utility, and are only } \\
\text { ready to bear risks in accordance with their preferences }\end{array}$ & Management \\
\hline & & $\begin{array}{l}\text { Intervention of the family according to the percentage of control exercised by } \\
\text { the family }\end{array}$ & Family \\
\hline & & $\begin{array}{l}\text { Building a shared vision of the future and reconciling inevitable conflicts } \\
\text { becomes extremely difficult. Role conflicts. }\end{array}$ & The owners \\
\hline $\begin{array}{l}\text { Typical risks } \\
\text { linked to the } \\
\text { functioning of }\end{array}$ & Family dynamics & $\begin{array}{l}\text { Intra-family conflicts. Notable divergences with the following generations. } \\
\text { Decrease in confidence. Rivalries can appear between brothers and sisters. } \\
\text { Succession periods are often the time when family ties are weakened }\end{array}$ & Family \\
\hline internal & & Dissatisfaction of employee when conflicts become chronic & Stakeholders \\
\hline
\end{tabular}




\section{processes and \\ the \\ safeguarding \\ of assets}

The presence or failure of the family unit
The impact of intra-family conflicts exceeds the family to contaminate the Management company and the management by altering its functioning

The concentration of family shareholding would limit the exercise of market discipline and would have a negative impact on financial value, It would also cause a misappropriation of wealth by family controllers (shareholders with significant control) which would be to the detriment of minority. The investment diversion for personal purposes.

When family unity is extremely achieved, it can lead to strong family control over the business. As the family grows and disperses, the correspondence between family values and company values becomes more and more difficult to Family ensure. The recognition of a risk of rupture of this unit is important. managing this risk should be a priority for the family business, especially in a complex family context. Confusion of legacy (business capital and wealth of families)

These conflicts would be exacerbated by the dispersal of property within the family. Divergence of interests between the family members who run the business, often with a majority stake and the other owner members.

In professional family companies, the separation between management and ownership is at the root of type I agency conflicts. In this type of companies, there is an absence of alignment of interests and weakness of family control, the type I conflict is strong. Type II agency conflict is apparent in controlled and mandated type family businesses, because the convergence of interests between the managers and the owner family shareholders leads to the expropriation of minority shareholders

Conflicts related to The sources of conflict can arise in particular when the rules are not established family control and or followed in general, and family ties often causes a worsening of the problem. agency conflicts

These conflicts involve either family members of the same generation, or of different generations, or oppose family members to outside employees. Conflicts of interest between family members occupying different roles in the business create a situation that can jeopardize collaboration and even the exchange of information .

One can feel the family bond as a form of " preference " and therefore of superiority on the part of the one who wears it. The family businesses that hire both members of the family and others who are outside, they frequently stakeholders experience conflicts over shortcomings with the rules established within the company

The opportunistic vision of the manager when the founder is part of the

Risks linked to management and / or administration of the company. Agency conflicts in these behavioural bias : companies are associated with entrenchment. the realization by the manager of (The shareholder specific investments makes it expensive to replace him and allows him to obtain directing the family a higher remuneration, greater advantages and more latitude to determine the business between strategy of the company. In this case, the family business is structurally led to be personal sustainability a place of conflict and non-alignment of interests. Altruism can force the family and organizational leader to take reckless measures that could potentially have harmful sustainability. The consequences for all stakeholders. That reduces the ability of the leader to rooting - transmission effectively control and discipline family members.

dilemma ) :

As soon as the capital is dispersed among several members, the shareholder / Risks related to manager relationship becomes a source of agency conflicts, leaving more singular governance. leeway to the manager. The selfless individual always expects something in Risks related to the return for what he gives. The absence of symmetry of altruism is the source of extension of several dysfunctions. The asymmetry of altruism between the family members governance to social follows the perceptions of injustice and of a support loss.

networks and Nepotism: Practices considered as certain segregation, causing misfortunes stakeholders. within the company and accused of harming its performance. Altruism can lead The bias of nepotism. family members to withhold information and thus create agency problems. The Altruism bias. family ties make it more difficult to fix certain types of conflicts and especially the mitigation of unproductive behaviour. According to theory, it can make it
The owners

\section{Management}

The owners Family

\section{Management}

The owners

Family 
more difficult for family members to enforce the agency contract. Worsening the vision of family heads. The behaviour of 'the child' who risks behaving as a stowaway, either by leaving it to others to complete a task that he started, either by negligence in wasting the parent's money, or by remaining dependent on the parents. Financing bodies, suppliers, customers etc. are no less important than other networks. It requires monitoring and vigilance on the part of the organization's leaders.

The nepotism decreases employee morale and hinders the activities especially if the people hired are looking for a position without fulfilling their responsibilities. has a tendency for the receiver to waste the donation quickly in Stakeholders order to receive more resources from another agent and to behave like a "whiner".

In some cases where several members of the family are all predisposed to

Risks imputed to the succeed, therein lies the problem of selection. Next generation motivation to selection of managers take over family business has fallen to a floor (successor problem). The managers are often selected by and from family members

The risk Created in the company by the change of the management teams (the Successors). the "wrong" choice of an heir can expose the entire family sphere to the weakening circumstances of a badly negotiated succession

The difficulties characterize this succession phase, such as the agreement on the value of the company, the choice of mode of transfer of shares, repayments relating to the estate, and the guarantee of a retirement predecessor. Neglect of The owners the preparation of the succession yet "necessary for the double maintenance of family harmony and business continuity". Estate planning that deals with certain Risks linked to aspects to the exclusion of others is doomed to failure.

succession-transmission Succession creates problems even within the family: the management teams exchange (the Successors); change in shareholding (heirs); weakening of the financial structure (sharing of shares or social shares); uncertainty about the visibility of the project (intra-family conflicts). The personal wishes of the heir Family and the predecessor are paramount in the construction of a context favourable to a succession: 1) without the consent of the heir the family succession has no meaning, 2) If the predecessor does not show the desire to transmit the company to the heir the whole operation will be in a status quo situation.

The family businesses are experiencing information asymmetry. Executives can manipulate information so that only information that serves their interests is shared and made public. The opportunism of managers increases the risk of alteration of the financial publication.

The family control over the administration board reduces the effectiveness of

Risks related to the independent directors to monitor the quality of financial information. When the Typical risks transparency of board is dominated by non-independent directors, complicity between them and related to the financial information other directors can arise, which has the effect of damaging the interests of reliability of Concentration of shareholders and the transparency of the company.

financial and ownership and the risk When the functions of CEO and Chairman of the Board are hold by the same non-financial of expropriation of person, threatening managerial control as long as this person, in his capacity as information minority shareholders Chairman of the Board, would be more aligned with the direction than with and Family control and shareholders. Severe agency conflicts between majority and minority compliance risks of altering shareholders. Conflicts between controlling shareholders and minority with laws and financial information shareholders. Opportunities for expropriation of the minority. The rooting regulations problem is emerging and is located between family shareholders who are for self-financing and minority shareholders who opt for the distribution of dividends. Under the effect of the concentration of capital, the dominant shareholders control managers and tend to appropriate their private benefits. The family control increases the risk of expropriation of minority shareholders

Risks related to The family businesses should avoid the risk of legal redress and facing various accounting and problems of regulatory compliance related to the auditor's qualification of the Management financial organization accounts, the change of auditor and the late filing of accounts because they are 


$$
\begin{aligned}
& \text { and information } \\
& \text { Compliance risk }
\end{aligned}
$$
results of the family business often indicators of financial difficulties.

In controlled family companies, the rooting effect makes it possible to maximize the wealth of controlling shareholders on the detriment of minority shareholders, which has a negative impact on the quality of financial information. As for the mandated company, risk of non-alignment between the interests of controlling shareholders and those of external managers. This has a negative impact on transparency and on the quality of financial information. In professional family companies, the non-family manager adopts a behaviour of non-alignment with the controlling shareholders. This divergence leads to a lower quality of financial information.

The unity of view between shareholders and managers, trust and acceptance of dialogue in the company seem very weak. Each of the actors of the family Non-financial $\quad$ shareholders-members of the family, the managers members of the family,
sheed adopt opportunistic behaviours, whether they are the information Ethics and social responsibility issues

children in their relationships with their shareholder parents.

The family business as an ambivalent organization, where the strong bond between employees and managers can turn into blind obedience, and lead to all excesses, and where emotional ties can promote harmony, but also destructive hatreds.

Note. The global mapping of risks specific to the family business, are listed as a resume to the literature we have exposed in this paper. We have agreed that the table in appendix make our cartography more clear and simple for readers.

\section{Conclusion}

The objective of this study was to propose an analytical framework that helps decipher and anticipate managing risks of the family business dysfunctions presumably hampering the family business government. The categorization of these risks is of high importance because it helps identifying potential risks according to their sources. Overall, three categories of risks were identified, these risks categories have allowed us to analyze the main risks of the family business on many levels: Strategic, Operational, Reporting and Compliance.

This revue suggests that the formulation of some proposals should be of more depth in order to achieve an accurate risk mapping of family businesses, comprehensive and formalized. Beyond this, the strategic interest for family businesses in such work, reside in the ability to assess the importance of each category of risk in order to grasp its impact and be able to define in a relevant way the adequate tool to protect itself against it. This study clearly indicates influencing factors in the evolution of the family business, mainly the complexity that resides in the capital being spread internally among family members and external ones. The effect of family control requires further analytical investigations of potential risks to strive for completeness. Mapping the risks of the family business are of utmost importance and we have laid the first foundations in this paper.

\section{References}

Akbar, M., \& Joshi, M. (2012). Endogenous agency problems, their impact and mitigation in privately-held family firms for sustaining growth. Amity Business Journal, 1(2), 1-22.

Altman, E. I., Sabato, G., \& Wilson, N. (2010). The value of non-financial information in small and medium-sized enterprise risk management. The Journal of Credit Risk, 6(2), 1-33.

AMF (Autorié des Marchés Financiers) (2010). Risk management and internal control systems, terms of reference.

Antonio, J. R. (2018). Does Family Involvement in Management Reduce the Risk of Business Failure? The Moderating - Role of Entrepreneurial Orientation.

Arteaga, R., \& Susana, M. R. (2017). Family Constitution and Business Performance: Moderating Factor. Family Business Review, 30.

Basly, S. (2007). Ownership, decision and strategy of the family business: A theoretical analysis.

Bernard, C. (2014). Family Risk Management Policies.

Berrone, P., Cruz, C., \& Gomez, M. L. (2012). Socioemotional Wealth in family firms: Theoretical dimensions, assessment approaches, and agenda for future research. Family Business Review, 25(3) 
Bianco, M., Bontempi, M., Golinelli, R., \& Parigi, G. (2013). Family firm’s investments, uncertainty and iscepopacity. Small Business Economics.

C.BERNARD. (2015). European Family Business Trend.

Cadiou, C, Cadiou, K., \& Ngoma, F. (2015). The value of family unity XXIVth International Conference on Strategic Management (AIMS).

Casillas, J. C., Moreno, A. M., \& Barbero, J. L. (2011). Entrepreneurial orientation of family firms: Family is

Chibani-Ltaief, F., \& Henchiri, J. E. (2016). The financial structure of family businesses: an analysis based on the theory of Pecking Order RED-ISG Gabes Tunisia Article.

COSO. (2013). the Committee of Sponsoring Organizations of the Treadway Commission (COSO II).

Crystal, J. H. F. (2015). Family-owned Businesses Struggle to Manage Risks. Risk and Compliance Journal.

Daniell, M. H., \& Mc Cullough, T. (2013). Family wealth management. Singapore: John Wiley and Sons Singapore Pte. Ltd.

Daugherty, M. S. (2013). Performance in the family business: Financial and socioemotional outcomes. In R. L. Sorenson, A. Yu, K.H. Brigham and G.T. Lumpkin, (Eds.), The Landscape of Family Business.

Dipietro, B. (2015). Family-owned Businesses Struggle to Manage Risks. Risk and Compliance Journal.

Downing, A. (2012). Risk management for financial families. Wells Fargo Bank, N. A.: Wells Fargo \& Company.

Fassler, M. L., \& Sage-Hayward, W. (2015). Managing Risk in the Family Enterprise: It's More Than Financial. The Family Business Consulting Group firms. Family Business Review.

González, M., Guzmán, A., Pombo, C., \& Trujillo, M. A. (2013). Family firms and debt: Risk aversion versus risk of losing control. Journal of Business Research, 66(11), 2308-2320.

Gudmonson, D., Hartman, A., \& Tower, B. (1999). Strategic orientation: Differences between family and nonfamily.

Hiebl, M. R.W. (2013). Risk aversion in family firms: What do we really know? Journal of Risk Finance.

Hirigoyen, G. (2008). Biais Comportementaux Dans L’Entreprise Familiale: Antecedents Et Impacts.

Hirigoyen. G, (2017). Altruisme du dirigeant et biais comportementaux dans l'entreprise familiale.

Joshi, M., \& Srivastava, A. (2013). Family business in transition: A case of PAL (Panchamrit Asbestos Ltd). Journal of Entrepreneurship in Emerging Economies. [iّep?

Le Breton-Miller, I., Miller, D., Lester, R. H. (2013). Stewardship or agency? A social embeddedness reconciliation of conduct and performance in public family businesses. In J.H. Astrachan, K.S. McMillan and T.M. Pieper (Eds.), Family Business (Vol. 111). New York

Memili, E., Chrisman, J. J., \& Chua, J. H. (2011). Transaction costs and outsourcing decisions in small and medium-sized family firms. Family Business Review.

Ouhadouch. S (2016). Results management and family involvement in governance: The case of listed French companies, Magellan Research Center University Lyon 3.

Salloum, L. (2015). Family businesses Taking managerial and organizational stakes in performance, Edition Bart et Jones.

Segalen. M, Attias, C. D. (2007). Grandparents. The family across the generations.

Visser, T., \& Van Scheers, L (2018). Can Family Business Managers Manage Family Business Risks? https://doi.org/10.30924/mjcmi/2018.23.1.123

Welsh, D. H. B., \& Zellweger, T. (2010). Can we afford it? Investment decisions of family and non-family owners. Academy of Entrepreneurship Journal.

Wilson, N., Wright, M., \& Scholes, L. (2013). Family business survival and the role of boards. Entrepreneurship Theory and Practice.

Zahra, S. A. (2013). Entrepreneurial risk taking in family firms. In J. H. Astrachan, K. S. McMillan \& T. M. Pieper, (Eds.), Family Business (Vol. 4). New York: Routledge.

Zellweger, C. F., \& Sieger, E. (2016). A joint study by Ernst \& Young SA AvS - International Trusted Advisors 
$\mathrm{GmbH} \cdot$ Chair in personnel management and intercultural leadership, ESCP Europe.

\section{Notes}

Note 1. The internal control objectives which can be classified into the following four categories:

- Strategic: strategic objectives serving the mission of the organization.

- Operational: objectives for the effective and efficient use of resources.

- Reporting: objectives related to the reliability of reporting.

- Compliance: objectives for compliance with applicable laws and regulations.

"By helping to prevent and control the risks of not achieving the objectives that the company has set for itself, the internal control system plays a key role in the conduct and management of its various activities." IFACI, Research notebook, Internal control and quality, (May 2008).

Note 2. AMF, Risk management and internal control systems, reference framework, Posted on June 14, 2010.

Note 3. IFACI and PwC France, the integrated internal control referential, a book translating the first two volumes of the COSO Report update, published in May 2013.

Note 4. Sami Basly Property, decision and strategy of the family business: A theoretical analysis article of November 29, 2007 on https://halshs.archives-ouvertes.fr

Note 5. Entrepreneuriat familial et stratégies de pérennité : contribution au concept d'innovation prudentielle Sihem Ben Mahmoud-Jouini - Sophie Mignon . 2009.

Note 6. Laura Salloum, Family businesses Taking managerial and organizational stakes in performance, Edition Bart et Jones, 2015.

Note 7. Berrone, P., Cruz, C., \& Gomez- Mejia, L. (2012). Socioemotional Wealth in family firms: Theoretical dimensions, assessment approaches, and agenda for future research. Family Business Review, 25 (3) http://www.sagepublications.com

Note 8. Sami Basly Ownership, decision and strategy of the family business: A theoretical analysis article of 29 Nov 2007 on https://halshs.archives-ouvertes.fr

Note 9. Mohamed Nabil EL MABROUKI, et al (2012), «L'effet des contraintes financières sur les entreprises familiales : du fatalisme à l'action ", 12th Annual IFERA World Family Business Research Conference, Bordeaux.

Note 10. Cadiou Christian Cadiou Kristen Ngoma Farrel The value of family unity XXIVth International Conference on Strategic Management (AIMS )

Note 11. Martine Segalen, Claudine Attias- Donfut. Grandparents. The family across the generations, Editions Odile Jacob, 2007

Note 12. The definitions of a stakeholder vary between authors. In the most restricted view, the concept of stakeholder designates the groups essential to the survival of the company. The Stanford Research Institute (1963) gives the following definition: "any identifiable group on which the organization depends for its long-term survival". In the broader view, proposed by Freeman (1984, p.46), "a stakeholder is an individual or group of individuals who can affect or be affected by the achievement of organizational goals". According to Charreaux and Desbrières (1998, p.58) "it is an agent whose utility is affected by the decisions of the firm". As for Clarkson (1995, p. 92-117), he considers that one cannot speak of interest without introducing the concept of risk. According to this approach, the organization and production of wealth require the involvement of different stakeholders. All may suffer the economic risk they take in the relationship with the company.

Note 13. Laura Salloum, Family businesses Taking managerial and organizational stakes in performance. Op.Cit.

Note 14. Philanthropy as a personal commitment to invest money, time and / or skills in family business general interest initiatives can have similar impacts to altruism if it is not carried out using a rational approach and regular evaluation and monitoring. The philanthropist acts with his means, dispossessing himself of all or part of his wealth, while pursuing in exchange either the acquisition of power, recognition, or any personal interest. Like altruism the problem can arise when there is an asymmetry in philanthropy between members of the family business. Like altruism, philanthropy would have the same consequences.

Note 15. F. Chibani-Ltaief \& JE Henchiri The financial structure of family businesses: an analysis based on the theory of Pecking Order RED-ISG Gabes Tunisia Article. Retrreived from 
https://www.researchgate.net/publication/313242028

Note 16. (Cf. Zellweger, Sieger and Englisch, 2016). A joint study by • Ernst \& Young SA • AvS - International Trusted Advisors $\mathrm{GmbH} \cdot$ Chair in personnel management and intercultural leadership, ESCP Europe Wirtschaftshochschule Berl

Note 17. Sadek OUHADOUCH, Gestion des résultats et implication familiale au sein de la gouvernance. (2016)

Note 18. Thea Visser and Louise van Scheers can family business managers manage family business risks? https://doi.org/10.30924/mjcmi/2018.23.1.123

Note 19. Sadek Ouhadouch . Op.Cit.

Note 20. Shiraz Ben Ali, quality e publishing financial è re and $\mathrm{m}$ é mechanisms of governance France, Management Prospective No. 61 2013/3

Note 21. Holders of large blocks of shares (or dominant shareholders) are more likely to take control of the firm and only publish information that serves their interests.

Note 22. Art.12-4 of the Dahir bearing law 1-93-212 as amended and supplemented - Art. III.2.1 CDVM circular

Note 23. Reference framework for risk management and internal control (AMF) systems Posted on July 22, 2010

Note 24. For more details on these criteria, see : the Decree of July 19, 2006 approving the professional practice standard in France, relating to the audit procedures implemented by the auditor at the end of its risk assessment $\mathrm{h}$ ttps: //www.legifrance.gouv.fr/eli/arrete/2006/7/19/JUSC0620547A/jo/texte

Note 25. By way of illustration, the Moroccan Code of Good Corporate Governance Practices, " the company must communicate as much as possible about its social, societal and environmental policy and its ethical and deontological rules" CGEM, March 2008

Note 26. Information ecurity, Préventica dated. Retrieved from https://www.preventica.com/dossier-cartographie-risques

\section{Copyrights}

Copyright for this article is retained by the author(s), with first publication rights granted to the journal.

This is an open-access article distributed under the terms and conditions of the Creative Commons Attribution license (http://creativecommons.org/licenses/by/4.0/). 